UDC: 316.012

DOI: https://doi.org/10.32689/26172224-2019-18-3-461-477

\section{Tertychnyi Oleksandr Vasyliovych,} Independent Scholar, Coordinator of the Joint Project Group, 03134, Kyiv, Symyranka str., 13/1, apartment 28, tel.: +38 0935709848 , e-mail:tertychnyi@gmail.com

ORCID: 0000-0003-4034-5196

\section{Тертичний Олександр Васильович,} незалежний дослідник, координатор групи “Спільний Проект", 03134, Київ, вул. Симиренка, 13/1, кв. 28, тел.: +38093 5709848, e-mail:tertychnyi@gmail.com ORCID: 0000-0003-4034-5196

\section{Тертычный Александр Васильевич,} независимый исследователь, координатор группы “Спільний Проект”, 03134, Киев, ул. Симиренко, 13/1, кв. 28, тел.: +38093 5709848,email:tertychnyi@gmail.com

ORCID: 0000-0003-4034-5196

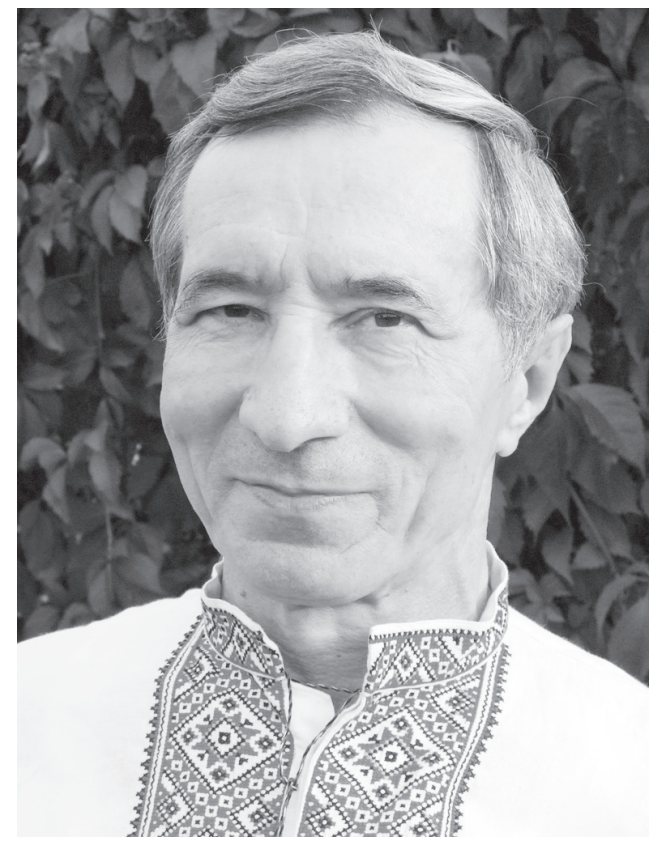

\title{
UKRAINIAN ARCHETYPE AS A SOURCE OF EUROPEAN SECURITY
}

Abstract. The publication proceeds from the fact that the destruction of the world security system has become both a sign and a consequence of the recent crisis in the West. Of the total set of reasons, the attention of the authors is attracted by the loss of landmarks and meanings, the departure from the basic values, softening of norms and taboos. The consequence was a dangerous reduction of public trust, which, in fact, is based on democracy.

As you know, in these circumstances, the hopes of many Western intellectuals appealed to Ukraine: "Today, the Ukrainian Maidan represents Europe at its best ... Let us help Ukrainians build a new Ukraine - and then they will certainly help us build a new Europe and a more just world".

So Maidan combined two historical processes: the improvement of Ukrainian society and traditional democracies. FUNDAMENTAL European values were sought by both Ukrainians and European intellectuals, but the process of renewal was slowed down: the results of five years do not suit either Ukrainians or Europeans. In Ukraine, the first vice president of the National Academy of Sciences of Ukraine, director of the National Institute for Strategic Studies Volodymyr Horbulin, wrote in 2016, the main brake became the feudal-oligarchic system, the radical restructuring of which is the first precondition for victory 
over the aggressor and the restoration of territorial integrity and state sovereignty.

Similar conclusion was previously arrived by citizens who in 2012 founded an interdisciplinary group of independent researchers of the Joint Project. The group has put forward the concept of de-oligarchy and sustainable development, which proceeds from the fact that the country's renewal is possible only with mass support of citizens. They should receive an attractive and true prospect of development of the country and the National Roadmap. The current reformers do not have a similar perspective, they did not receive mass support, which, in particular, showed Ukrainian politicians losing their "new face" in the presidential elections on March 31, 2019.

During 2012-17, the Joint Project modeled the Positive scenario, which provides and justifies this perspective. The System Technology Research Agency provided a review of the Document, which stated, in particular, that the Positive scenario could be recommended as a draft unification platform program.

The publication attracts attention to those Scenario fragments that reflect similar features of Ukrainian and Western European processes, and thus open up possible directions for cooperation between Ukrainian and foreign researchers.

Keywords: Ukrainian archetype, entelechy, network democracy, personal mandate, "yellow vests", public sociology, deoligarchy.

\section{УКРАЇНСЬКИЙ АРХЕТИП І ЄВРОПЕЙСЬКА БЕЗПЕКА}

Анотація. Публікація виходить з того, що руйнування світової системи безпеки стало як ознакою, так і наслідком новітньої кризи Заходу. Із усієї сукупності причин увагу авторів привертають втрата орієнтирів і сенсів, відхід від базових цінностей, розм'якшення норм і табу. Наслідком стало небезпечне зменшення суспільної довіри, на якій, власне, і грунтуються демократії.

Як відомо, в таких умовах сподівання багатьох західних інтелектуалів звернулися до України: “Сьогодні український Майдан представляє Європу в найкращому вигляді... Дозвольте нам допомогти українцям побудувати нову Україну - і тоді вони, безумовно, допоможуть нам побудувати нову Європу і більш справедливий світ".

Так Майдан поєднав два історичних процеси: оздоровлення українського суспільства і традиційних демократій. ФУНДАМЕНТАЛЬНИХ європейських цінностей прагнули як українці, так і європейські інтелектуали, але процес оновлення загальмувався: результати п'яти років не влаштовують ні українців, ні європейців. В Україні головним гальмом стала феодально-олігархічна система, докорінна перебудова якої є першою передумовою перемоги над агресором та відновлення територіальної цілісності й державного суверенітету - написав у 2016 р. перший віце-президент НАН України, директор Національного інституту стратегічних досліджень Володимир Горбулін.

Аналогічного висновку раніше прийшли громадяни, які у 2012 р. заснували міждисциплінарну групу незалежних дослідників “Спільний Проект”. 
Група висунула концепт деолігархізації і сталого розвитку, який виходить 3 того, що оновлення країни можливе лише за масової підтримки громадян. Вони мають отримати привабливу і правдиву перспективу розвитку країни та Національну Дорожню карту. Подібної перспективи чинні реформатори не мають, масової підтримки не отримали, що, зокрема, засвідчив і програш українського політикуму “новому обличчю” на виборах президента 31 березня 2019 р.

Протягом 2012-2017 рр. “Спільний Проект” змоделював концепт Позитивний сценарій, який передбачає і обгрунтовує таку перспективу. Агенція досліджень системних технологій надала рецензію на Документ, де зазначила, зокрема, що Позитивний сценарій може бути рекомендований як проект програми об'єднавчої платформи.

Публікація привертає увагу до тих фрагментів сценарію, які відображають схожі риси українських і західноєвропейських процесів, отже, відкривають можливі напрями співпраці українських та іноземних дослідників.

Ключові слова: український архетип, ентелехія, мережана демократія, персональний мандат, “жовті жилети”, публічна соціологія, деолігархізація.

\section{УКРАИНСКИЙ АРХЕТИП КАК ИСТОЧНИК ЕВРОПЕЙСКОЙ БЕЗОПАСНОСТИ}

Аннотация. Публикация исходит из того, что разрушение мировой системы безопасности стало как признаком, так и следствием нового кризиса Запада. Из всей совокупности причин внимание авторов привлекают потеря ориентиров и смыслов, уход от базовых ценностей, размягчение норм и табу. Следствием стало опасное уменьшение общественного взаимодоверия, на котором, собственно, и основываются демократии.

Как известно, в таких условиях надежды многих западных интеллектуалов обратились к Украине: “Сегодня украинский Майдан представляет Европу в лучшем виде ... Позвольте нам помочь украинцам построить новую Украину - и тогда они, безусловно, помогут нам построить новую Европу и более справедливый мир”.

Так Майдан объединил два исторических процесса: оздоровление украинского общества и традиционных демократий. К ФУНДАМЕНТАЛЬНЫМ европейским ценностям стремились как украинцы, так и европейские интеллектуалы, но процесс обновления затормозился: результаты работы пяти лет не устраивают ни украинцев, ни европейцев. В Украине главным тормозом стала феодально-олигархическая система, коренная перестройка которой является первой предпосылкой победы над агрессором и восстановления территориальной целостности и государственного суверенитета написал в 2016 г. первый вице-президент НАН Украины, директор Национального института стратегических исследований Владимир Горбулин.

К аналогичному выводу ранее пришли граждане, которые в 2012 г. основали междисциплинарную группу независимых исследователей “Спільний Проект”. Группа выдвинула концепт деолигархизации и устойчивого разви- 
тия, который исходит из того, что обновление страны возможно только при массовой поддержке граждан. Они должны получить привлекательную и правдивую перспективу развития страны и Национальную Дорожную карту. Подобной перспективы действующие реформаторы не имеют, массовой поддержки не получили, что, в частности, показал и проигрыш украинского политикума “новому лицу” на выборах президента 31 марта 2019 г.

В течение 2012-2017 гг. "Спільний Проект” смоделировал концепт Позитивный сценарий, который предсказывает и обосновывает такую перспективу. Агентство исследований системных технологий предоставило рецензию на документ, где отметило, в частности, что Позитивный сценарий может быть рекомендован как проект программы объединительной платформы.

Публикация привлекает внимание к тем фрагментам сценария, которые отражают сходные черты украинских и западноевропейских процессов, следовательно, открывают возможные направления сотрудничества украинских и иностранных исследователей.

Ключевые слова: украинский архетип, энтелехия, облачная демократия, персональный мандат, “желтые жилеты”, публичная социология, деолигархизация.

Formulation of the problem. In 2010, the owner of the portal Netzpolitik.org Markus Bekedal said that leading German politicians overslept the Internet, where is the birth of the fifth power, and now politicians must learn to communicate with civil society [1]. The author's concept comes from both aspects of the diagnosis: social networks have opened a new era of civilization [2], and the political elite does not have time to react to the parabolic acceleration of social development [3].

The collapse of the world security space logically follows from the internal crisis of a mighty West. The loss of landmarks and meanings, the departure from basic values and the easing of norms and taboos has led to a decrease in confidence in western countries. Lowering confidence is destroying democratic societies. In particular, US President Barack Obama of the rostrum of the General Assembly of the United Nations in 2016 acknowledged: "... the world is by many standards less violent and more prosperous than ever before, nevertheless, our societies are full of uncertainty, anxiety and discord. Despite the tremendous progress, people are losing confidence in the institutions ..." [4].

One of the hallmarks of this process was mass protests, the first wave of which took place in 2011: in the spring and summer in Europe under the motto REAL DEMOCRATIE YA, and in autumn and winter in the US under the slogan Occupy Wall Street. President of the International Sociological Association, Immanuel Valerstane, noted that this was the most important political event in the United States since $1968 \ldots$... [5].

From the fall of 2018, "yellow waistcoats" do not stop, which actually ex- 
tended the wave of 2011. They have already forced the French president to accept part of their demands, then to hold an unprecedented national debate to "hear the French". But that was not enough to stop the protests, and further events remain unpredictable.

The Ukrainian school of archetype explains this process from the standpoint of the universal social cycle: "The society of transitional state (revolution and coevolution) is undergoing institutional changes, during which social structures and social norms are eroded, social relations weaken and even rupture during inversion, the hierarchy of factors is violated, which constitute mechanisms for the reproduction of social structures" [6, 12].

The expectations of eight dozen Western intellectuals appealed to Ukraine: "Today, the Ukrainian Maidan represents Europe at its best - in a way that many thinkers of the past and present have defined fundamental $\mathrm{Eu}-$ ropean values ..." [7].

On Maidan, two historical processes have been united: the improvement of Ukrainian and pan-European societies. Both the Ukrainians and the European intellectuals sought the fundamental values of Europe.

The author concept took into account the change in the European disposition that Bernard-Henri Levy formulated as follows: "This Europe seems to have petrified during the Maidan, it is Europe that does not dare to raise its voice on Putin - it is a frightened Europe, afraid. This is Europe, which no longer believes in itself - of course, such a disappointing Europe. So there is the idea of Europe, which now carries Ukraine ..." [8].
The general contours of a successful Ukraine and the Roadmap were presented by the Joint Project at the 2nd Congress of the Sociological Association of Ukraine [9]. The said author concept confirmed and filled the real life of the Maidan, which began one month after Congress. The Swiss economist, a former member of the Club of Rome, futurist Bogdan Havrylyshyn emphasized: "There was no competition on the Maidan, but all the necessary services were created: not by order of the government, but through a sense of duty to their fellow citizens and the country... This motivation is fantastic. Thus, our people have already begun to act in accordance with this new paradigm for which the world must live. We do not have to overcome the whole world - whether it's Europe or the United States ... There is very little need for a Ukrainian economic miracle to begin. I think that the beginning may be two years, but total transformations are needed" [10].

Unfortunately, the hoped total transformations were blocked by the feudal-oligarchic system. The first vice president of the National Academy of Sciences of Ukraine, Volodymyr Horbulin, in 2016 stressed: "A radical restructuring of this system is the first precondition for the victory over the aggressor and the restoration of territorial integrity and state sovereignty" [11].

It is possible to conduct a de-oligarchy only at a certain level of mutual trust in society, with the mass support of citizens. They should receive an attractive development prospect, because without vision of the future there can be no unity or inspiration. In theory, 
such a perspective should be provided by the State Strategy, but it still does not exist in Ukraine.

Analysis of recent research and publications. The reaction to the lack of a state strategy was the activity of public "strategists". They simulated their vision of the future as "project objectives" - for the subsequent creation of the State Strategy. Have put forward a lot of original ideas, worked out many interesting concepts. But none is consistent with the Ukrainian archetype, the historical mission and the aspirations of the nation [12].

The number of visions is increasing, and determination of the best of them has not yet been possible. In response to such uncertainty at the V TMS 2014 seminar, the third group of dynamic networks recommended the STRATEGY OF OUTPUT OF UKRAINE FROM SYSTEM CRISIS [13], which consists of 12 abstracts. № 1: The Strategy should begin with the definition of a socially acceptable Goal of Ukraine's development in the foreseeable future. Ten abstracts are provided by the backbone of the first edition of the Positive scenario of the Joint Project.

The Next, 2015 year, the Decree of the President of Ukraine approved the Strategy for Sustainable Development "Ukraine - 2020". Unfortunately, the document does not match the title: in essence, this package is not structured according to the priorities of intentions and wishes. In particular, the movement was foreseen in four vectors and at the same time implemented 62 reforms and programs. The purpose of the Strategy was to declare within 5 years "the introduction of European standards of life in Ukraine and Ukraine's emergence of leading positions in the world" [14]. The unreliability of those intentions was evidenced by the practice.

The Foundation for Future (fff) research community has adopted the contractual principle as a methodological basis. The draft Social Contract created by its leading participation contains many interesting ideas and useful innovations. But the subject of the implementation of the Treaty in the documents remains open, as in other "visionaries" [15].

Under the scientific guidance of the academician of the National Academy of Sciences of Ukraine M. Zgurovsky, a large "Foresight of the economy of Ukraine" was created in 2015. The document contains in-depth analysis, many useful predictions and recommendations. By the horizon of 2030, the probability of future scenarios Forsyth determined pessimistic: "Alien subjectivity" - about $30 \%$, Gray Zone 15-18 \%, Disintegration - about $5 \%$, balanced development (positive option) $-2 \%$. At the same time, Forsyth leaves hope for the implementation of the least likely scenario of "balanced development": thanks to the people of Ukraine, whose actions can not be foreseen $[16,136]$.

The authors acknowledged the limited technological foresight, which implies the need to resort to futuristic methods. The same need, already in 2018, was recognized by Volodymyr Horbulin, the first vice president of the National Academy of Sciences of Ukraine, director of the National Institute for Strategic Studies, who called for "to give at least some understandable and futuristicly acceptable benchmark" [17]. 
Particular attention is drawn to the developments of the Ukrainian school of archetype. Many of its axioms, observations and conclusions coincide with some of the nodes of the author's Vision. Both directions, at least in part, are based on metaphysical concepts, both emphasizing the new, subjective role of the person, both came to the optimistic prediction of the Future of Ukraine.

At the same time, the Positive scenario was originally created as a research project (based on Imre Lakatos' theory). Therefore, the prediction of the Joint Project has become only a basis for further development of the methods of current targeted influence on the future. The author's vision of the Ukrainian dream [18] has become only one of the important nodes in the process of finding a common goal, a roadmap and a social subject.

The purpose of the article is to outline the possibilities of disseminating the values of the future and practical experience of Maidan ("maidan" archetype) to create a consolidated system of security and sustainable development: both in Ukraine and in European countries. An important condition for success is the dismantling of the oligarchic System, which threatens the very existence of sovereign Ukraine.

Presentation of the main research material. From the beginning of 2015, public administration in Ukraine is aimed at rebuilding the System. New institutions have been created, leading public authorities have recruited recognized foreign professionals, donors and lenders have funded civic activists and media support. There are certain results: essentially "cleared" NJSC "Naftogaz of
Ukraine", reformed administrative service and banking sector, patrol police, public procurement system ...

However, most of the innovations turned out to be a traditional imitation. Cleansing, lustration and contests for the post were held by trusted people who have been linked by common interests and mutual obligations in the past. The renovation of structures is so slow that it gives the System time to "crush" new, out-of-system people: to buy, to intimidate, to squirm on.

"We were used" - recognized representatives of a number of public organizations under the control of "Avtoomaydanu", which began to control the certification of police officers. Following, a similar statement was promulgated by the Public Council of Integrity, which did not manage to clear the judicial corporation.

The falsity of such a course has shown the greatest decrease in the trust of Ukrainians in power (up to $9 \%$ [19]), and the notable defeat of the Ukrainian politics in the presidential election of March 31, 2019. More than 30 percent of the votes that received a "new face" were apparently not voices FOR an unknown neophyte candidate, but a protest AGAINST living standards, the failure of the anti-corruption campaign and disregard for society by the authorities after the Revolution of Dignity.

The conclusion about the mistakenness of the current policy has been already come and by some of its supporters and participants. Quite authoritative experts have explicitly stated: "... some international agencies and donor governments, including their em- 
bassies in Kyiv, have a fairly superficial idea of corruption in Ukraine" [20]. The authors hope that the West will change its policy on Ukraine to "correct", but underestimate the internal contradictions of their hopes. For, in the same cited article, it is fairly stated that state institutions do not represent the interests of citizens who, in their turn, do not trust them.

So in 2019, the reformers finally came up to the problem, which was promulgated by five years ago a very competent person - Andriy Yermolayev. He left the position of the head of the National Institute for Strategic Studies on the eve of the day and publicly stated: state institutions in Ukraine were privatized [21]. That is, the reformers have an object, but there is no subject of reform.

For independent researchers, the problem was evident a long time ago, and in the year 2012, a Joint Project was created to find a solution to it. The Group has developed a Positive scenario, which received a favorable review by the Agency for the Study of System Technologies [22].

Positive scenario as a model of public sociology. The appeal of civil activists to the problems of social philosophy and futurology became a public reaction to the limited dominant form of sociological thinking, as sociologist Y. Yakovenko determined [23]. Public same researchers do not depend on the state and the market, free in the choice of subject and methods. In particular, they do not feel the pressure of scientific authorities, not connected with conservative forms and conventions, have the opportunity and need a public format. This allows to overcome the spe- cific constraints of both "professional" and "applied" sociology.

The subject of the study was also very specific to the "visionaries": the Strategic Goal of Ukraine and the Roadmap to it. In order to "catch up", the Joint Project had to be guided by the principle of minimum sufficiency, which became the basis of the ad hok methodology (in this case). At first, they discovered a minimum of key rappers of the historical process, and put everything behind the brackets: to keep from the rupture the boundary line, outlining the essence and ensuring the integrity of the concept. In fact, this method is a condensed version of the principle of a minimal universe.

The condition for the completion of the concept needed the logical search chain to the strategic Ukrainian Goal, and (returning) to a concrete answer to the practical question: what to do today?

However, in order to see the Vision, it was necessary to understand the essence of the Goal, and it could not be formulated outside the vision of the historical horizon. On the other hand, the Goal will be achievable if it relies not only on predictions but on a basis that already exists or needs to be developed. To understand the integrity of the Vision, it is necessary to find out the meaning of its constituent parts, but parts, separately in their understanding and purpose, become open only on condition of clarity gestalt features of the Vision [24].

Thus the circle is closed: the implementation of the Vision requires the subject - the subject needs the Program - the program should be based on the Visuals Platform. 
Social subject of modernization. The bearers of the latest "Maidan" archetype can be estimated from 3 to 10 percent of Ukrainians. The lower limit is the share of volunteers [25], and the higher is the proportion of participants in the Maidan. Keeping the eastern outpost and inspiring the hopes of tired Europe, they should take care of the following problem: the rise of socio-economic and technological development of the country.

Most sociologists and political scientists attribute hopes for modernization with the middle class. It has long been considered the basis of Western democracy, in particular, because the aspiration of personal liberty among its representatives prevailed for the desire of wealth and power. However, over time, there are more and more questions that cast doubt on the role of the "hegemon of democracy".

The Ukrainian Center for Economic and Political Studies named after O. Razumkov identified the following socio-class groups: the upper class $1 \%$; middle class $-14 \%$; middle class periphery $-35 \%$; lower class $-31 \%$. Percentage shows that the revealed middle class has an unusual position of the highest class for the tradition, since $1 \%$ is obviously made up of representatives of large capital. And the middle position (the next $35 \%$ ) is occupied by the population attributed to the PERIPHERY of the class: according to the Center's methodology, their material wealth, the quality of education and culture, and the real status in society do not reach the indicators of "conditional" middle class.

Our middle class is NOT the bearer and defender of democracy, but it should be. He plays the role of a social stabilizer, that is, the Conservative System, but has no signs of freedom. The authors recall that in this case it is possible to agree with some researchers who believe that the middle class has not always played a progressive role in society" [26].

Meanwhile, as the Joint Project suggests, Maidan and the war have launched a new social stratum in Ukraine - responsible. Traditionally, the emerging freedom-loving community, the authors of the concept define the term class. Its specificity is, in particular, that the basis is made up of purely Ukrainian social communities: maidanivtsi and volunteers. Their interests coincide with the vector of perspective development of society, which offers a Positive scenario.

Some psychologists are paying attention to the important feature of this class: after the front, volunteers are trying to return to the life they fought in the war: the same corruption, theft, social injustice, etc. With this new/old life, most veterans will never agree.

The script takes into account that the freedom-loving class is at the stage of formation and self-awareness. Right now, intellectuals can play the "engineering" function of its formation - in accordance with the transition from the state of "class in itself" to the state of "class for itself". UCEPS researchers hope for such a transformation of another (middle) class.

It should be recalled that Professor Michael Burava noted: public sociology involves participation in the creation and transformation of public structures [27]. This is exactly what the Joint Project did when it discovered 
and disseminated information about the specific interests and values of the responsible class, the differences or coincidences with the interests of other communities.

Unified platform for the subject. The vision of the future and the Roadmap should become the subject of the modernization program. The most significant aspects of the Scenario are focusing on the concept of a Single Vision (common vision) of the future of Ukraine and the methodology for creating the Strategy and Program for the Implementation of Reform [28]. As a startup package for the country's renewal, in 2017, the script proposed to put forward a unifying memo "personal mandate". This is a legal innovation, which is intended to convey the actual control of elected persons directly to the hands of citizens. A vote cast for a candidate or a party, each voter must be able to withdraw before the end of the current term. If the chooser does not fulfill the conditions for political lending (for example, he votes against promises), he violates the conditions for the use of the loan. Thus, the lendervoter has grounds to stop lending at a time when he has verified the violation of the agreement.

The concept of the Personal Mandate implies the introduction of an electronic voting, similar to that already in place in some countries. In this case, "termination of lending" can take place in the same convenient way as voting: dial the corresponding personal code on your phone or computer - and press the enter key. When the number of withdrawn votes reaches a critical mark (for example, 15 or $20 \%$ ), the mandate is automatically canceled - without interference from any intermediate instance [29].

The unified idea proceeds from the fact that the Verkhovna Rada is unlikely to adopt the Law on the introduction of a personal mandate without prolonged extra-system pressure. Such a pressure could trigger a "Personal Mandate" civil campaign, which would gradually consolidate a significant part of civil society, and hence its structures. Such a campaign does not require significant expenses for functionaries and agitation: each public structure has the ability to initiate the creation of local cells by the forces of its activists.

Collaboration on the implementation of the Mandate can be a joint project of all the social and ethnic structures of the nation. In order to avoid starting competition for the ideological flag of consolidation, the Joint Project has done the following with the slogan "make and go": announced the refusal of hypothetical participation in the organizational stage of creating a unifying platform [30].

The attractiveness of the Personal Mandate, as a possible unifying goal, is confirmed both in the expert and in the political environment. Mikhail Saakashvili became the first well-known politician who publicly acknowledged and personally substantiated the social need for a Personal Mandate. In a video address in the summer of 2018, he formulated the essence of innovation in his words: voters do not need to believe in politicians - they must be controlled under the threat of immediate recall [31]. The video with this speech received 147,000 views and 3,177 broadcasts. 
At a later stage of consolidation, the availability and transparency of the initiative can be ensured by the use of an LiquidFeedback type IT platform (current feedback). The appropriateness of such a platform is evidenced by the experience of its use by some European parties in Germany, Spain, Sweden.

Conclusions and perspectives of further research. The role of the Ukrainian archetype as a source of European security stems from the leading spiritual position of Ukraine in European processes. The essence of the new phenomenon, the French philosopher Bernard-Henri Levy, fixed the metaphor: "... there is an idea of Europe, which now carries Ukraine”.

It is impossible to restore the system of international security without overcoming the internal crisis of Western civilization. Significant obstacles to the path to sustainable development were oligarchic consequences, which destroyed the foundations of democracy - public trust. Ukraine suffers the most from this trouble, where, according to Volodymyr Horbulin, the first vice president of the National Academy of Sciences of Ukraine, the problem has already become existential.

The anticorruption campaign of financial and diplomatic pressure on the power of donors and allies, the direct participation of their representatives in the internal processes of a positive change did not bring.

A different view of solving the problem is provided by a multidisciplinary team of independent researchers in the Joint Project. The author hypothesis is based on the well-known properties of systems: they have mechanisms for protection and self-reproduction in the event of damage. In particular, the oligarchic system available in Ukraine has absorbed key elements of the state apparatus and local self-government bodies. Therefore, they can not operate at the expense of the System, and automatically issue simulations.

To replace the current system and simultaneously create another system requires a powerful outsystem entity a mass non-partisan platform. Taking into account the presence of the "maidan" archetype of Ukrainians, a responsible class can become a healing subject, which is now undergoing a stage of self-awareness. Consolidation of civil society can take place on the unifying Platform - according to Ortega-iHassetti's idea of a joint project of the future that can only unite a modern nation.

The Visiting Project of such a Platform may become the concept of the Positive scenario of the Joint Project. According to the Independent System Research Institute, the scenario proposed constructive steps towards convergence of civic movements and communities in order to consolidate them in confronting the oligarchic System and accelerating the implementation of reforms.

Publication can be viewed as one of the new approaches to safe and sustainable development in a civilizational shift. The author hypothesis suggests that in the medium term (by 2030) European countries can build, together with Ukraine, a new security system. To do this, you should master the latest insights on the current state of human development and technology of work with the Future, make significant adjustments to public administration. 
The co-operation of some Ukrainian and Western European problems provides grounds for international consolidation to overcome the crisis. From the Ukrainian side Joint Proposal may be put forward for joint consideration. For example, the idea of embroidered democracy as a new political idea, which, according to sociologist Etienne Balibara [32], is currently lacking in Europe.

The start-up package of mass movement in Ukraine proposes the consolidation of civil society around the implementation of the Personal Mandate. The concept of this legal innovation was supported by many Ukrainian intellectuals, the first of which was the famous law-constitutionalist professor Victor Musiyaka. Recently, the innovation was interested also by the professor at the University of Paris V - Sorbonne, founder of Michel Muffesol's Center for the Study of the Contemporary Today.

At the very least, the author's concept was taken into account as an appeal of Western intellectuals to help Ukrainians now, and their hopes for helping Ukrainians "build a new Europe and a more just world".

\section{REFERENCES}

1. Khavronin A. (July 14, 2011). Itogi internet-borby s plagiatom v Germanii [Results of the Internet fight against plagiarism in Germany]. www.svobodanews.ru. Retrieved from http:// www.svobodanews.ru/content/transcript/24266277.html [in Russian].

2. Tertychnyi O. (2010, November 26). Kamo hriadeshy? Do merezhevoi demokratii, zvychaino zh! [Quo Vadis? To network democracy, of course!]. Ukrainska pravda -
Ukrainian Truth. Retrieved from https://www.pravda.com.ua/columns/2010/11/26/5601111/ [in Ukrainian].

3. Poveshchenko H., Chekhovyi Yu. (2001). Matematychna model strukturnoi evoliutsii suspilnykh produktyvnykh syl [Mathematical model of structural evolution of social productive forces]. Zhurnal Instytutu sotsiolohii NAN Ukrainy "Sotsiolohiia: teoriia, metody, marketynh" Journal of the Institute of Sociology of the National Academy of Sciences of Ukraine "Sociology: Theory, Methods, Marketing", 3, 41-59. Retrieved from http://i-soc.com.ua/ journal/N3_2001r_3.pdf [in Ukrainian].

4. Holinata A. (September 20, 2016). Obama: "Narod Ukrainy ne vyishov na vulytsi cherez yakus zakordonnu zmovu..." [Obama: "The people of Ukraine did not go out on the street because of some kind of foreign conspiracy ...”]. ukrainian.voanews.com. Retrieved from https://ukrainian. voanews.com/a/vystup-obamy-nageneralniy-asamblei-oon/3517249. html [in Ukrainian].

5. Wallerstein I. (October 19, 2011). The Fantactic Success of Occupy Wall Street. www.zcommunications. org. Retrieved from www.zcommunications.org/the-fantastic-successof-occupy-wall-street-by-immanuelwallerstein\# [in English].

6. Afonin E. A., Martynov A. Yu. (2018). Arkhetypy indyvidualnoho i kolektyvnoho v modeli universalnoho sotsialnoho tsyklu [Archetypes of Individual and Collective in the Model of the Universal Social Cycle]. Publichne Uriaduvannia - Public Management, 4 (14), 18-33 [in Ukrainian].

7. Support Ukrainians and they can helpus build a fairer Europe. (January 3, 2014). www.theguardian.com. Re- 
trieved from https://www.theguardian.com/world/2014/jan/03/support-ukrainians-build-fairer-europe [in English].

8. Makarov Yu. (February 20, 2015). Bernar Anri-Levi: Ukraina nosyt ideiu Yevropy [Henri-Levi Bernard: Ukraine Bears the Idea of Europe]. hromadskeradio.org. Retrieved from http://hromadskeradio. org/2015/02/20/bernar-anri-leviukrayina-nosit-ideyu-yevropi/ [in Ukrainian].

9. Tertychnyi O. V. (2013). Kontseptsiia merezhanoi demokratii yak pozytyvnyi forsait-stsenarii [The concept of network democracy as a positive forsite script]. II Konhres Sotsiolohichnoi asotsiatsii Ukrainy $-2^{\text {nd }}$ Congress of the Sociological Association of Ukraine: Proceedings of reports. (p. 374-375). Kharkiv [in Ukrainian].

10. Havrylyshyn B. (February 4, 2015). Za dva roky $\mathrm{v}$ Ukraini pochnetsia ekonomichne dyvo [An economic miracle will begin in Ukraine in two years]. 1-12.org.ua. Retrieved from http://1-12.org.ua/2015/02/04/3379 [in Ukrainian].

11. Horbulin V. (February 12, 2016). Chy ye zhyttia pislia Minska? [Is there life after Minsk?]. dt.ua. Retrieved from https://dt.ua/internal/chi-yezhittya-pislya-minska-mirkuvannyaschodo-neminuchostineobhidnihzmin.html?fbclid=IwAR1n8ezLo18H9 qcJeXVFKy7cCGvU122R52jhJu9yZPQMlvvBx4K0vXreOmg [in Ukrainian].

12. Tertychnyi O. (July 7, 2015). Chotyry Bachennia maibutnoho Ukrainy [Four Visions of the Future of Ukraine]. www.facebook.com. Retrieved from https://www. facebook.com/notes/spilnyiproekt/chotyry-bachennia-maibutnoho-ukrainy/734020860057143 [in Ukrainian].
13. Sushyi O. V., Bielska T. V., Tertychnyi O. $V$. (2014). Stratehiia vykhodu ukrainy iz systemnoi kryzy [Strategy of Outcome of Ukraine from System Crisis]. Ukrainskyi sotsium - Ukrainian society, 2 (49), 128-134 [in Ukrainian].

14. Ukaz Prezydenta Ukrainy "Pro Stratehiiu staloho rozvytku "Ukraina-2020" : id 12.01.2015, № 5/2015 [Decree of the President of Ukraine "On the Strategy of Sustainable Development "Ukraine 2020" from 12.01.2015, № 5/2015]. zakon.rada.gov.ua. Retrieved from http://zakon4.rada. gov.ua/laws/show/5/2015\#n10 [in Ukrainian].

15. Proekt Suspilnoho dohovoru [Draft Public Contract]. sdukr.com. Retrieved from https://sdukr.com/contract [in Ukrainian].

16. Zghurovskyi M. Z. (2015). Forsait ekonomiky Ukrainy: serednostrokovyi (2015-2020 roky) i dovhostrokovyi (2020-2030 roky) chasovi horyzonty [Foresight of Ukraine's economy: medium-term (2015-2020) and longterm (2020-2030) time horizons]. Kyiv: NTUU "KPI" [in Ukrainian].

17. Horbulin V. (June 15, 2018). Vulkanichnyi syndrom [Volcanic syndrome]. Dzerkalo tyzhnia - Mirror of the week [in Ukrainian].

18. Tertychnyi O. (September 08, 2010). Ukrainian dream: korydor pryntsypovo novykh mozhlyvostei [Ukrainian dream: a corridor of fundamentally new opportunities]. Ukrainska pravda - Ukrainian Truth. Retrieved from https://www.pravda.com.ua/ columns/2011/12/25/6841586/ [in Ukrainian].

19. Bikus Z. (March 21, 2019). WorldLow $9 \%$ of Ukrainians Confident in Government. news.gallup.com. Retrieved from https://news.gallup. com/poll/247976/world-low-ukrainians-confident-government.aspx [in English]. 
20. Dubrozskyi V., LafJ. (March 5, 2019). Ukraina maie zoseredytysia radshe na zapobihanni koruptsii, a ne pokaranni. Velykyi antykoruptsiinyi analiz [Ukraine should focus more on preventing corruption, not punishment. Big Anticorruption Analysis]. voxukraine.org. Retrieved from https://voxukraine.org/uk/ukrayinamaye-zosereditisya-na-zapobigannikoruptsiyi-a-ne-pokaranni-velikij-antikoruptsijnij-analiz/ [in Ukrainian].

21. Kotliar A. (February 7, 2014). Yermolaiev Andrii: "Krainoiu keruie korporatsiia. Derzhavni instytuty pryvatyzovano" [Yermolayev Andriy: "The country is governed by a corporation. State institutions are privatized"]. dt.ua. Retrieved from https:// dt.ua/socium/andriy-yermolayevkrayinoyu-keruye-korporaciya-derzhavni-instituti-privatizovano-_.html [in Ukrainian].

22. Romanov M. M. (November 8, 2017). Retsenziia na hromadskyi proekt "Pozytyvnyi Stsenarii" [Review of the public project "positive scenario"]. drive.google.com. Retrieved from https://drive.google.com/file/d/1lV Rf3QxGf822nKT46pMU7hmyLvpBdIRa/view?fbclid=IwAR1hx3p9gi qPel8C3AomtFHTNvVpjh8aSFz2t0PrOjwrpTdCnPzH7wUo [in Ukrainian].

23. Yakovenko Yu. I. (2012). Sotsiolohiia $v$ suchasnii Ukraini: chy ye rukh vpered? [Sociology in modern Ukraine: Is there movement ahead?]. Mizhnarodnyi naukovyi forum: sotsiolohiia, psykholohiia, pedahohika, menedzhment - International scientific forum: sociology, psychology, pedagogy, management, 8, 5-32 [in Ukrainian].

24. Tertychnyi O. (2017). Entelekhiia yak modelist pozytyvnoho stsenariiu [Entelechy as a modelist of a positive scenario]. Ukraina v humanitarnykh i sotsialno-ekonomichnykh vymirakh Ukraine in Humanitarian and SocioEconomic Dimensions: Proceedings of the $2^{\text {nd }}$ All-Ukrainian Scientific Conference March. (Vols. 1). Dnipro [in Ukrainian].

25. Volonterskyi rukh: svitovyi dosvid ta ukrainski hromadianski praktyky [Volunteer Movement: World Experience and Ukrainian Civic Practices]. (2015). Kyiv: NISD [in Ukrainian].

26. Rachok, A., et. al. (2016). Serednii Klas v Ukraini: Uiavlennia i Realii [The Middle Class in Ukraine: Views and Realities]. Kyiv: UTsEPD imeni Oleksandra Razumkova. razumkov. org.ua. Retrieved from http://razumkov.org.ua/uploads/article/2016 Seredn_klas.pdf [in Ukrainian].

27. Burazoy M. (n.d.). Za publichnuyu sotsiologiyu [For public sociology]. (A. Baldzhi, Trans). E. YarskayaSmirnova, P. Romanov (Eds.). Retrieved from http://publicsphere. narod.ru/Burawoy.pdf [in Russian].

28. Tertychnyi O. V. (2018). Ukrainskyi Shliakh: Do Pryideshnoi Peremohy [Ukrainian Way: To Future Win]. Suspilno-Politychni Protsesy Vypusk Social-Political Processes, 3 (10), 319-366 [in Ukrainian].

29. Tertychnyi O. V. (2014). Personalnyi Mandat [Personal Mandate]. Aktualni problemy suchasnoho suspilstva $\mathrm{v}$ fokusi sotsiolohii - Actual problems of modern society in the focus of sociology: Proceedings of the All-Ukrainian Scientific and Practical Conference. Kyiv: Milenium [in Ukrainian].

30. Personalnyi mandat yak merezha natsionalnoi konsolidatsii [Personal mandate as the netherlands consolidation network]. (2017). drive.google.com. Retrieved from https://drive.google.com/ file/d/1hvvyLA0cmwktrBYMO zLOlO_88iDZz7/view?usp=sharing [in Ukrainian]. 
31. Saakashvili M. (n.d.). Nam nuzhen ynstrument bustroho yspravlenyia oshybok [We need a quick fix tool]. www.facebook.com. Retrieved from https://www.facebook.com/SaakashviliMikheil/ videos/2002915003072204/ [in Russian].

32. Balibar E. (December 13, 2018). Gilets jaunes: le sens du face à face. blogs. mediapart.fr. Retrieved from https:// blogs.mediapart.fr/etienne-balibar/ blog/131218/gilets-jaunes-le-sensdu-face-face [in French].

\section{СПИСОК ВИКОРИСТАНИХ ДЖЕРЕЛ}

1. Хавронин А. Итоги интернет-борьбы с плагиатом в Германии [Электронный ресурс] / Радіо Свобода, 14 Июль 2011. - Режим доступа: http://www.svobodanews. $\mathrm{ru} /$ content/transcript/24266277. html

2. Тертичний О. Камо грядеши? До мережевої демократії, звичайно ж! [Електронний ресурс] // Українська правда, 26 листоп. 2010. - Режим доступу: https://www.pravda.com. ua/columns/2010/11/26/5601111/

3. Повещенко Г., Чеховий Ю. Математична модель структурної еволюції суспільних продуктивних сил [Електронний ресурс] // Журнал Ін-ту соціології НАН України "Соціологія: теорія, методи, маркетинг”. - 2001. - № 3. - С. 41-59. Режим доступу: http://i-soc.com.ua/ journal/N3_2001r_3.pdf.

4. Голіната А. Обама: "Народ України не вийшов на вулиці через якусь закордонну змову..." [Електронний ресурс] / Українська редакція Радіо Голос Америки, 20 верес., 2016. Режим доступу: https://ukrainian. voanews.com/a/vystup-obamy-nageneralniy-asamblei-oon/3517249. html
5. Immanuel Wallerstein "The Fantactic Success of Occupy Wall Street" // Особиста сторінка Імануела Валерстайна. 19 жовт. 2011 [Електронний ресурс]. - Режим доступу: /www. zcommunications.org/the-fantasticsuccess-of-occupy-wall-street-byimmanuel-wallerstein\#

6. Афонін Е. А., Мартинов А. Ю. Архетипи індивідуального і колективного в моделі універсального соціального циклу // Публічне урядування (Public management). червень 2018 (спецвип.). - № 4 (14). - К.: ДП “Вид. дім “Персонал”, 2018.

7. Support Ukrainians and they can helpus build a fairer Europe [Електронний ресурс] / The Guardian, Friday 3 January 2014. - Режим доступу: https://www.theguardian. com/world/2014/jan/03/supportukrainians-build-fairer-europe

8. Бернар Анрі-Леві. Україна носить ідею Європи [Електронний ресурс] / Громадське радіо, 20 лют. 2015. - Режим доступу: http://hromadskeradio. org/2015/02/20/bernar-anri-leviukrayina-nosit-ideyu-yevropi/

9. Тертичний О. В. Концепція мережаної демократії як позитивний форсайт-сценарій / II Конгрес Соціологічної асоціації України. - Х., 2013. Тези доповідей. - С. 374-375.

10. Гаврилишин Б. За два роки в Украіні почнеться економічне диво [Електронний ресурс] // Сайт Ініціативи 1 грудня. 4 лютого 2015. Режим доступу: http://1-12.org. ua/2015/02/04/3379

11. Горбулін В. Чи є життя після Мінська? [Електронний ресурс] //Дзеркало тижня. 12 лютого 2016 р. Режим доступу: https://dt.ua/ internal/chi-ye-zhittya-pislyaminska-mirkuvannya-schodoneminuchostineobhidnihzmin.html?fb clid=IwAR1n8ezLo18H9qcJeXVFKy 
7cCGvU122R52jhJu9yZPQMlvvBx4 K0vXreOmg

12. Тертичний O. Чотири Бачення майбутнього України. [Електронний pecypc] // ФБ-група Спільний Проект, Файли 7 липня 2015. - Peжим доступу: https://www.facebook. com/notes/спільний-проект/чотири-бачення-майбутнього-україни/734020860057143

13. Суший О. В., Бєльська Т. В., Тертичний $O$. В. Стратегія виходу України із системної кризи // Український соціум. - 2014. - № 2 (49).

14. Про Стратегію сталого розвитку “Україна - 2020". Указ Президента України [Електронний ресурс] / Платформа Верховної Ради України. - Режим доступу: http://zakon4. rada.gov.ua/laws/show/5/2015\#n10

15. Проект Суспільного договору [Електронний ресурс] / сайт "Новий суспільний договір”. - Режим доступу: https://sdukr.com/contract $\backslash$

16. Форсайт економіки України: середньостроковий (2015-2020 роки) i довгостроковий (2020-2030 роки) часові горизонти / наук. керівник проекту акад. НАН України М. 3. Згуровський. - К. : НТУУ “КПІ", 2015.

17. Горбулін В. Вулканічний синдром // Дзеркало тижня. -15 черв. 2018 р.

18. Тертичний $O$. Ukrainian dream: коридор принципово нових можливостей [Електронний ресурс] // Українська правда. -8 верес. 2010. - Режим доступу: https://www.pravda.com. ua/columns/2011/12/25/6841586/

19. World-Low $9 \%$ of Ukrainians Confident in Government [Електронний ресурс] // Сайт Gallup MARCH 21, 2019. - Режим доступу: https://news.gallup.com/ poll/247976/world-low-ukrainiansconfident-government.aspx

20. Дубровський В., Лаф Дж. Україна має зосередитися радше на запо- біганні корупції, а не покаранні. Великий антикорупційний аналіз [Електронний ресурс] /платформа VoxUkraine березень 5, 2019. - Peжим доступу: https://voxukraine. org/uk/ukrayina-maye-zosereditisyana-zapobiganni-koruptsiyi-a-nepokaranni-velikij-antikoruptsijnijanaliz/

21. Єрмолаєв А. "Країною керує корпорація. Державні інститути приватизовано" [Електронний ресурс] // Дзеркало тижня. - 7 лют., 2014. - Режим доступу: http:// gazeta.dt.ua/socium/andriyyermolayev-krayinoyu-keruyekorporaciya-derzhavni-institutiprivatizovano-. $\mathrm{html}$

22. Рецензія на громадський проект "Позитивний сценарій” [Електронний ресурс] // Агенція досліджень системних технологій, 08.11.2017. ежим доступу: https://drive. google.com/file/d/1lVRf3QxGf8 22 n KT 46pMU 7 hmy Lvp BdIRa/ view?fbclid=IwAR1hx3p9gi_qPel8C 3AomtFHTNvVpjh8aSFz2t0Pr0jwrp $\mathrm{TdCnPzH7}$ wU

23. Яковенко Ю. І. Соціологія в сучасній Україні: чи є рух вперед? [Електронний ресурс] /Міжнародний науковий форум: соціологія, психологія, педагогіка, менеджмент. 2012. - Режим доступу: Mnf_2012_8_3

24. Тертичний $O$. Ентелехія як моделіст позитивного сценарію // Матеріали II Всеукраїнської наукової конференції 24-25 берез. 2017 p. - Ч. I. - С. 62. Дніпро, 2017.

25. Волонтерський рух: світовий досвід та українські громадянські практики: аналіт. доп. - К.: НІСД, 2015. $36 \mathrm{c}$.

26. Середній клас в Україні: уявлення і реалії [Електронний ресурс] / УЦЕПД ім. Олександра Разумкова, с. 11. - Режим доступу: 
http://razumkov.org.ua/uploads/ article/2016_Seredn_klas.pdf

27. Буравой М. За пуббличную социологию [Электронный ресурс] / пер. А. Балджи; под ред. Е. Ярской-Смирновой и П. Романова. Режим доступа: http://publicsphere. narod.ru/Burawoy.pdf

28. Тертичний $O . \quad B . \quad$ Український шлях: до прийдешньої перемоги / О. В. Тертичний // Суспільно-політичні процеси. - Вип. 3 (10). 2018. - C. 319-366.

29. Тертичний O. В. Персональний мандат / О. В. Тертичний // Актуальні проблеми сучасного суспільства в фокусі соціології: Матеріали всеукраїнської науково-практичної конференції, м. Київ, 19 берез. 2014 р. - К.: Міленіум, 2014. C. 45 .
30. Персональний мандат як мережа національної консолідації [Електронний ресурс] // Спільний Проект, 2017. - Режим доступу: https://drive.google.com/ file/d/1 hvvyLA0cmwktrBYMO zLOlO_88iDZz7/view?usp=sharing

31. Saakash̆rili M. Нам нужен инструмент быстрого исправления ошибок [Электронный ресурс] // Facebook блог Mikheil Saakashvili. Режим доступа: https://www. facebook.com/SaakashviliMikheil/ videos/2002915003072204/

32. Balibar E. "Gilets jaunes: le sens du face à face" [Електронний ресурс] // Mediapart, le blog de Etienne Balibar, 13 DÉC. 2018. - Режим доступу: https://blogs.mediapart.fr/etiennebalibar/blog/131218/gilets-jaunes-lesens-du-face-face 